\title{
Pedein A and B: Production, Isolation, Structure Elucidation and Biological Properties of New Antifungal Cyclopeptides from Chondromyces pediculatus (Myxobacteria)
}

\author{
Brigitte Kunze, Bettina Böhlendorf, Hans Reichenbach, Gerhard Höfle
}

Received: November 7, 2007 / Accepted: January 5, 2008

(C) Japan Antibiotics Research Association

\begin{abstract}
Two new secondary metabolites, named pedein $\mathrm{A}$ and $\mathrm{B}$, were isolated from the cell mass of the myxobacterium Chondromyces pediculatus. Their planar structures were elucidated by spectroscopic methods, in particular 2D NMR as 24-membered cyclic hexapeptides composed of a variable tryptophan residue, glycine, sarcosine and three unusual hydroxy $\beta$ - and $\gamma$-amino acids. The main component, pedein A, strongly inhibited the growth of yeasts and fungi, induced hemolysis of erythrocytes, and caused changes in membrane permeability of Rhodotorula glutinis. The structures of the pedeins are closely related to the large family of the microsclerodermins, which have been isolated from lithistid sponges of Microscleroderma and Theonella species.
\end{abstract}

Keywords myxobacteria, pedeins, cyclic peptides, antifungal

\section{Introduction}

Myxobacteria of the genus Chondromyces, suborder Sorangineae, have been shown to produce a variety of novel biologically active substances with different mechanisms of action. Thus, chondramides are inhibitors of the actin skeleton [1 3], crocacin and ajudazols are mitochondrial electron transport inhibitors at different sites
[4 7], and apicularens are specific inhibitors of V-ATPase [8 10]. Extracts of Chondromyces pediculatus, strain $\mathrm{Cm}$ p3 were noticed for their marked antifungal activity. HPLC/DAD/MS analysis of the extracts indicated the presence of six major components with molecular weights in the range of 781 to $924 \mathrm{mu}$ of which two were correlated with the antifungal activity. The compounds responsible were isolated by column chromatography of the cell extract and named pedein A (1) and B (2). A tentative structure of 1 was depicted in the GBF Scientific Annual Report 1993 and at the international conference of microbial secondary metabolism in Interlaken 1994 [11] anticipating the structures of the related microsclerodermins [12 14]. Here we describe in detail production, isolation, physicochemical properties and structure elucidation of $\mathbf{1}$ and $\mathbf{2}$ as well as biological properties of $\mathbf{1}$.

\section{Results}

\section{Production and Isolation}

In order to obtain smooth growth and reasonable cell densities, the producing organism had to be adapted to growth in liquid media by 4 to 8 transfers in shaken cultures. After that, the strain could be cultivated also in media based on technical substrates, e.g., Probion (single cell protein prepared from Methylomonas clarae; Hoechst AG, Frankfurt), soy flour, or oatmeal. Table 1 shows the
B. Kunze (Corresponding author): Helmholtz Centre for Infection Research, Research Group Microbial Communication, Inhoffenstr. 7, D-38124 Braunschweig, Germany,

E-mail: brigitte.kunze@helmholtz-hzi.de
H. Reichenbach, G. Höfle: Helmholtz Centre for Infection Research, Inhoffenstr. 7, D-38124 Braunschweig, Germany

B. Böhlendorf: Present address: Syngenta AG, CH-4002 Basel, Natural Products 
effect of various technical substrates on the yields of $\mathbf{1}$ in 100-ml shake cultures of Chondromyces pediculatus strain $\mathrm{Cm}$ p3. By increasing the concentration of the technical substrates from 0.4 to $0.9 \%$ the amount of 1 usually decreased, with the exception of oatmeal, in which $\mathbf{1}$ production increased up to $11.9 \mathrm{mg} /$ liter.

The production of pedeins on a larger scale was performed in bioreactors containing media on the basis of different technical substrates. Yet comparable amounts of $\mathbf{1}$ as produced by cultivating strain $\mathrm{Cm} \mathrm{p} 3$ in shake cultures, could not be achieved. In a 65-liter fermentation batch described in the experimental section, $\mathbf{1}$ accumulated after 7 days at the end of the fermentation to about $1.3 \mathrm{mg} / \mathrm{liter}$ as determined by HPLC. Isolation of pedeins was best achieved by extraction of the collected cell mass from

Table 1 Effect of various technical substrates on the production of pedein $A(\mathbf{1})$ in shake cultures

\begin{tabular}{lcc}
\hline $\begin{array}{c}\text { Substrate } \\
(\%)\end{array}$ & $\begin{array}{c}\text { Concentration } \\
\text { (mg/liter) }\end{array}$ & Pedein A titer ${ }^{\mathrm{b}}$ \\
\hline Probion & 0.4 & 3.7 \\
Skim milk powder & 0.4 & 3 \\
Soy flour & 0.4 & 8.0 \\
Peanut meal & 0.4 & 5 \\
Cornsteep powder & 0.4 & 0.2 \\
Oat meal & 0.4 & 8.2 \\
Oat meal & 0.9 & 11.9 \\
\hline
\end{tabular}

a The basal medium was: soluble starch $0.3 \%, \mathrm{MgSO}_{4} \cdot 7 \mathrm{H}_{2} \mathrm{O} 0.1 \%$; $\mathrm{CaCl}_{2} \cdot 2 \mathrm{H}_{2} \mathrm{O} 0.05 \%$; HEPES buffer $50 \mathrm{mM}$ (pH 7.2); supplemented with standard vitamin- and trace element solutions, $1 \mathrm{ml} /$ liter each. Harvest was at the end of the growth phase after about 5 days.

${ }^{b}$ The concentration of $\mathbf{1}$ was determined in acetone extracts of the cell mass by HPLC analysis. shake cultures followed by multi-step reversed phase chromatography. Thus, e.g. from 36 liters of shake cultures containing $113 \mathrm{mg}$ of 1 and $99 \mathrm{mg}$ of other metabolites $67 \mathrm{mg}$ of pure 1 and $8.0 \mathrm{mg}$ of 2 were isolated. Fig. 1 shows an analytical HPLC/DAD profile of a crude extract of $\mathrm{Cm}$ p3 after 7 days of cultivation. In addition to $\mathbf{1}$ and $\mathbf{2}$ four other major metabolites $\mathbf{3} \sim \mathbf{6}$ were observed characterized by specific UV spectra and molecular masses in the range of 700 to $900 \mathrm{mu}$. For the latter, however, no molecular ions or exact masses were obtained from the on-line ESI-MS measurements.

\section{Physico-chemical Properties and Structure Elucidation}

$\mathbf{1}$ and $\mathbf{2}$ were obtained as colorless solids, well soluble in dimethyl sulfoxide, DMF and pyridine, less so in methanol and chloroform. The physico-chemical properties of $\mathbf{1}$ and $\mathbf{2}$ are summarized in Table 2 . The pedeins are stable under normal laboratory conditions, however decomposed in sunlight. This was indicated by the decrease of both antifungal activity and UV absorption at $287 \mathrm{~nm}$. Catalytic hydrogenation of $\mathbf{1}$ led to a tetrahydro derivative (data not shown) stable in sunlight, however, with 10 times lower activity against Rhodotorula glutinis.

For 1 ESI-MS in the positive mode showed a very weak $[\mathrm{M}+\mathrm{H}]^{+}$ion at $925 \mathrm{mu}$ and strong $\left[\left(\mathrm{M}-\mathrm{H}_{2} \mathrm{O}\right)+\mathrm{H}\right]^{+}$and $[\mathrm{M}+\mathrm{Na}]^{+}$ions at 907 and $947 \mathrm{mu}$, respectively. Similarly FAB-MS gave a strong $\left[\left(\mathrm{M}-\mathrm{H}_{2} \mathrm{O}\right)+\mathrm{H}\right]^{+}$ion which, like in the ESI spectra, showed the $3: 1$ isotope pattern for chlorine. From HRFAB-MS (calc. 907.3393, found 907.3400) the elemental composition $\mathrm{C}_{43} \mathrm{H}_{53} \mathrm{ClN}_{8} \mathrm{O}_{13}$ was calculated, indicative of a peptide structure. Total hydrolysis of $\mathbf{1}$, derivatization and GC/MS analysis revealed the presence of glycine, sarcosine $(N$ methylglycine) and of an isomer of threonine. Strong IR

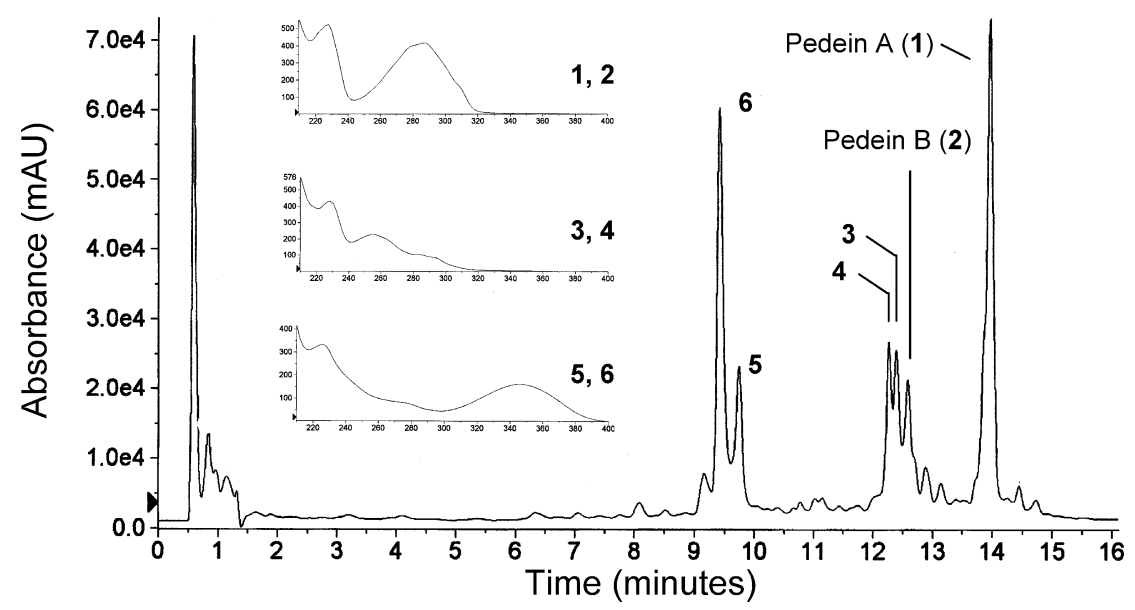

Fig. 1 HPLC/DAD chromatogram of a crude cell extract of Chondromyces pediculatus, strain Cm p3

Nucleodur $\mathrm{C} 18$ column, $\mathrm{CH}_{3} \mathrm{CN} / 5.0 \mathrm{mM}$ ammonium acetate buffer $\mathrm{pH} 5.5$, flow $0.3 \mathrm{ml} /$ minute, gradient $5: 95$ to $95: 5$ in 30 minutes. 
Table 2 Physico-chemical properties of pedein A (1) and B (2)

\begin{tabular}{|c|c|c|}
\hline & Pedein A (1) & Pedein B (2) \\
\hline Appearance & White powder & Colorless solid \\
\hline Molecular weight & $924 / 926$ & 890 \\
\hline$[\alpha]_{D}^{20}$ & -46.5 ( с 0.37 in DMSO/MeOH $2: 8$ ) & - \\
\hline Formula & $\mathrm{C}_{43} \mathrm{H}_{53} \mathrm{ClN}_{8} \mathrm{O}_{13}$ & $\mathrm{C}_{43} \mathrm{H}_{54} \mathrm{~N}_{8} \mathrm{O}_{13}$ \\
\hline UV-VIS $\left(\lambda_{\max }, n m\right)$ in $\mathrm{MeOH}$ & $\begin{array}{l}227(\varepsilon=47500), 278 \text { sh }(29600), 287 \text { (31500), } \\
\quad 295 \text { sh }(\varepsilon=26000), 309 \text { sh }(21500)\end{array}$ & $227,278 \mathrm{sh}, 287,307 \mathrm{sh}$ \\
\hline $\mathrm{IR} v_{\max }(\mathrm{KBr}) \mathrm{cm}^{-1}$ & $3386,2927,1732$ sh, 1674,1530 & - \\
\hline Rf on TLCa & 0.44 & 0.46 \\
\hline Rt (minute) on HPLC ${ }^{b}$ & 14.0 & 12.6 \\
\hline
\end{tabular}

a Silica gel TLC, solvent: EtOAc/MeOH/H $/ \mathrm{H}_{2} \mathrm{O}(80: 15: 10)$.

b See Fig. 1.

Table 3 NMR data of 1 in DMSO- $d_{6}$

\begin{tabular}{|c|c|c|c|c|c|c|}
\hline Residue & Group & $\delta^{13} \mathrm{C}$ & $\delta^{1} \mathrm{H}$ & Mult. & $J[\mathrm{~Hz}]$ & $\mathrm{HMBC}$ \\
\hline \multicolumn{7}{|l|}{ APTD } \\
\hline 1 & $\mathrm{CO}$ & 173.0 & & & & 2-H and/or Pyrr-4-H, Pyr-4-NH \\
\hline 2 & $\mathrm{CH}$ & 69.4 & 4.44 & $\mathrm{~m}$ & & $4-\mathrm{H}$ \\
\hline \multirow[t]{2}{*}{3} & $\mathrm{CH}$ & 53.1 & 4.19 & $\mathrm{~m}$ & & $5-H^{a}$ \\
\hline & $\mathrm{NH}$ & & 7.37 & $\mathrm{br}$ & & \\
\hline 4 & $\mathrm{CH}$ & 70.2 & 3.30 & $\mathrm{~m}$ & & $3-\mathrm{H}, 6-\mathrm{H}_{2}$ \\
\hline \multirow[t]{2}{*}{5} & $\mathrm{CH}$ & 69.1 & 3.52 & $\mathrm{~m}$ & & $5-\mathrm{OH}, 6-\mathrm{H}_{2}, 7-\mathrm{H}$ \\
\hline & $\mathrm{OH}$ & & 4.25 & br s & & \\
\hline \multirow[t]{2}{*}{6} & $\mathrm{CH}_{2}$ & 36.8 & 2.28 & ddd & $14 ; 7 ; 7$ & $4-\mathrm{H}, 5-\mathrm{OH}, 7-\mathrm{H}, 8-\mathrm{H}$ \\
\hline & & & 2.32 & ddd & $14 ; 7 ; 7$ & \\
\hline 7 & $\mathrm{CH}$ & 133.2 & 5.85 & ddd & $15 ; 7.5 ; 7.5$ & $4-\mathrm{H}, 6-\mathrm{H}_{2}, 9-\mathrm{H}$ \\
\hline 8 & $\mathrm{CH}$ & 131.8 & 6.24 & $d d$ & $15 ; 10.5$ & $6-\mathrm{H}_{2}, 9-\mathrm{H}, 10-\mathrm{H}$ \\
\hline 9 & $\mathrm{CH}$ & 129.4 & 6.85 & $d d$ & $15.5 ; 10.5$ & $\mathrm{H}-7, \mathrm{H}-8$ \\
\hline 10 & $\mathrm{CH}$ & 129.8 & 6.47 & $d$ & 15.5 & $8-\mathrm{H}, 12-\mathrm{H}, 16-\mathrm{H}$ \\
\hline 11 & $\mathrm{Cq}$ & 137.2 & & & & $9-\mathrm{H}, 10-\mathrm{H}, 13-\mathrm{H}, 15-\mathrm{H}$ \\
\hline 12,16 & $\mathrm{CH}$ & 126.0 & 7.43 & $d$ & 7.5 & $10-\mathrm{H}, 12-\mathrm{H}, 14-\mathrm{H}, 16-\mathrm{H}$ \\
\hline 13,15 & $\mathrm{CH}$ & 128.6 & 7.31 & $\mathrm{t}$ & 7.5 & $13-\mathrm{H}, 15-\mathrm{H}$ \\
\hline 14 & $\mathrm{CH}$ & 127.1 & 7.20 & $\mathrm{t}$ & 7.0 & $12-\mathrm{H}, 16-\mathrm{H}$ \\
\hline \multicolumn{7}{|l|}{ Pyrr } \\
\hline 1 & $\mathrm{CO}$ & 170.7 & & & & $2-\mathrm{H}_{2}$, Sark-2- $\mathrm{H}_{2}$, Sark-3- $\mathrm{H}_{3}$ \\
\hline \multirow[t]{2}{*}{2} & $\mathrm{CH}_{2}$ & 38.9 & 2.61 & $d$ & 17 & $4-\mathrm{H}$ \\
\hline & & & 2.83 & $d$ & 17 & \\
\hline 3 & $\mathrm{Cq}$ & 82.3 & & & & $2-\mathrm{H}_{2}, 4-\mathrm{H}$ \\
\hline 4 & $\mathrm{CH}$ & 56.2 & 4.45 & $\mathrm{~m}$ & & $3-\mathrm{NH}, 5-\mathrm{H}, 4-\mathrm{NH}^{\mathrm{a}}$ \\
\hline 5 & $\mathrm{CH}$ & 79.1 & 4.06 & $d$ & 9 & 3-NH, 4-H, 7- $\mathrm{H}_{3}$ \\
\hline 6 & $\mathrm{CO}$ & 171.5 & & & & $3-\mathrm{NH}^{\mathrm{a}}, 5-\mathrm{H}$ \\
\hline 7 & $\mathrm{CH}_{3}$ & 56.9 & 3.40 & s & & $5-\mathrm{H}$ \\
\hline 3 & $\mathrm{NH}$ & & 8.18 & br s & & \\
\hline 4 & $\mathrm{NH}$ & & 7.59 & d & 10 & \\
\hline \multicolumn{7}{|l|}{ Sark } \\
\hline 1 & $\mathrm{CO}$ & 170.2 & & & & Sark-2- $\mathrm{H}_{2}, \mathrm{Cl}-\mathrm{Trp}-2-\mathrm{H}^{\mathrm{a}}, \mathrm{Cl}-\mathrm{Trp}-2-\mathrm{NH}$ \\
\hline \multirow[t]{2}{*}{2} & $\mathrm{CH}_{2}$ & 49.6 & 3.69 & $d$ & 16 & $3-\mathrm{H}_{3}$ \\
\hline & & & 4.31 & $d$ & 16 & \\
\hline
\end{tabular}


Table 3 Continued

\begin{tabular}{|c|c|c|c|c|c|c|}
\hline Residue & Group & $\delta^{13} \mathrm{C}$ & $\delta^{1} \mathrm{H}$ & Mult. & $J[\mathrm{~Hz}]$ & $\mathrm{HMBC}$ \\
\hline $\begin{array}{l}3 \\
\mathrm{Cl}-\operatorname{Trp}\end{array}$ & $\mathrm{CH}_{3}$ & 36.3 & 2.93 & s & & $2-\mathrm{H}_{2}$ \\
\hline 1 & $\mathrm{CO}$ & 171.8 & & & & $2-\mathrm{H}, 3-\mathrm{H}_{2}$, Gly-2-NH, Gly-2- $\mathrm{H}_{2}$ \\
\hline 2 & $\begin{array}{l}\mathrm{CH} \\
\mathrm{NH}\end{array}$ & 55.5 & $\begin{array}{l}4.17 \\
8.68\end{array}$ & $\begin{array}{l}m \\
d\end{array}$ & 4 & 2-NH, 3- $\mathrm{H}_{2}$ \\
\hline 3 & $\mathrm{CH}_{2}$ & 26.0 & $\begin{array}{l}2.98 \\
3.11\end{array}$ & $\begin{array}{l}d d \\
d d\end{array}$ & $\begin{array}{l}14.5 ; 8.5 \\
14.5 ; 6.0\end{array}$ & $2-\mathrm{H}, 2-\mathrm{NH}$ \\
\hline $2^{\prime}$ & $\mathrm{CH}$ & 124.9 & 7.27 & br s & & $1^{\prime}-\mathrm{NH}, 3-\mathrm{H}_{2}$ \\
\hline $3^{\prime}$ & $\mathrm{Cq}$ & 111.0 & & & & $2-\mathrm{H}, 3-\mathrm{H}_{2}, 1^{\prime}-\mathrm{NH}, 2^{\prime}-\mathrm{H}, 4^{\prime}-\mathrm{H}$ \\
\hline $4^{\prime}$ & $\mathrm{CH}$ & 119.6 & 7.53 & $d$ & 8.5 & \\
\hline $5^{\prime}$ & $\mathrm{CH}$ & 118.6 & 7.00 & $d$ & 8.5 & $7^{\prime}-\mathrm{H}$ \\
\hline $6^{\prime}$ & $\mathrm{Cq}$ & 125.9 & & & & $4^{\prime}-\mathrm{H}$ \\
\hline $7^{\prime}$ & $\mathrm{CH}$ & 110.9 & 7.37 & br s & & $4^{\prime}-\mathrm{H}, 5^{\prime}-\mathrm{H}$ \\
\hline $8^{\prime}$ & $\mathrm{Cq}$ & 136.4 & & & & $2^{\prime}-\mathrm{H}, 1^{\prime}-\mathrm{NH}, 4^{\prime}-\mathrm{H}$ \\
\hline $9^{\prime}$ & $\mathrm{Cq}$ & 125.7 & & & & $2^{\prime}-\mathrm{H}, 3-\mathrm{H}_{2}, 5^{\prime}-\mathrm{H}, 1^{\prime}-\mathrm{NH}, 7^{\prime}-\mathrm{H}$ \\
\hline $1^{\prime}$ & $\mathrm{NH}$ & & 11.04 & br s & & \\
\hline Gly & & & & & & \\
\hline 1 & $\mathrm{CO}$ & 168.9 & & & & 2- $\mathrm{H}_{2}$, AHB-4-NH, AHB-4- $\mathrm{H}_{2}$ \\
\hline 2 & $\mathrm{CH}_{2}$ & 42.7 & $\begin{array}{l}3.37 \\
3.72\end{array}$ & $\begin{array}{l}\mathrm{m} \\
\mathrm{m}\end{array}$ & & $2-\mathrm{NH}^{\mathrm{a}}$ \\
\hline & $\mathrm{NH}$ & & 8.52 & $\mathrm{t}$ & 4 & \\
\hline $\mathrm{AHB}$ & & & & & & \\
\hline 1 & $\mathrm{CO}$ & 172.3 & & & & $2-\mathrm{H}_{2}$, APTD-3H, APTD-3N-H \\
\hline 2 & $\mathrm{CH}_{2}$ & 40.9 & $\begin{array}{l}2.14 \\
2.45\end{array}$ & $\begin{array}{l}d d \\
d\end{array}$ & $\begin{array}{l}14 ; 11 \\
14\end{array}$ & $4-\mathrm{H}_{2}$ \\
\hline 3 & $\mathrm{CH}$ & 66.8 & 3.79 & $\mathrm{~m}$ & & $2-\mathrm{H}_{2}, 4-\mathrm{H}_{2}$ \\
\hline 4 & $\mathrm{CH}_{2}$ & 45.0 & $\begin{array}{l}2.68 \\
3.31\end{array}$ & $\begin{array}{l}m \\
m\end{array}$ & & $4-\mathrm{NH}^{\mathrm{a}}$ \\
\hline 4 & $\mathrm{NH}$ & & 7.42 & br & & \\
\hline not assign. & $\mathrm{OH}$ & & $\begin{array}{l}6.18 \\
6.27\end{array}$ & $\begin{array}{l}\text { br s } \\
\text { brs }\end{array}$ & & \\
\hline
\end{tabular}

${ }^{a}$ Weak correlation

bands at 1674 and $1530 \mathrm{~cm}^{-1}$ and 7 carbonyl signals in the ${ }^{13} \mathrm{C}-\mathrm{NMR}$ spectrum in the range of 168.0 to $173.0 \mathrm{ppm}$ confirmed a peptide structure incorporating the remaining 7 nitrogen atoms. The strong UV band at $288 \mathrm{~nm}(\varepsilon=31500)$ was in good agreement with a 1-phenylbutadien chromophor (286 nm, $\varepsilon=28200$ [15]) derived from NMR data. A detailed analysis of COSY, TOCSY and HMBC data obtained from a DMSO- $d_{6}$ solution of 1 (Table 3) confirmed the presence of glycine, sarcosine and 6 ' chlorotryptophan, and identified three further unusual amino-acid residues abbreviated as APTD, AHB and Pyrr. APTD, carrying the UV chromophor, is a new amino acid, (7E,9E)-3-amino-10-phenyl-2,4,5-trihydroxy-deca-7,9dienoic acid. AHB is 4-amino-3-hydroxy-butyric acid. From its carbon backbone, Pyrr is 3-amino-4-keto-5- methoxy-hexadioic acid-6-amide, which in solution exists exclusively in its cyclic hemiacetal (pyrrolidinone) form. However, a shoulder at $1732 \mathrm{~cm}^{-1}$ in the IR spectrum indicates the presence of some keto form in $\mathrm{KBr}$. At this point 20 of 21 expected double bond equivalents were identified. The remaining double bond equivalent proved that $\mathbf{1}$ is a cyclic peptide, which is in good agreement with a negative ninhydrin test and the failure of the Edman degradation. A rigorous proof of the amino acid sequence came from a complete set of $\mathrm{C}, \mathrm{H}$ correlations across the six amide bonds forming the macrocyle of 1 (Figs. 2 and 3 ). The core structure of $\mathbf{1}$ is thus identical with that of the microsclerodermins $\mathrm{A} \sim \mathrm{I}$. With respect to the side chains, the closest relative of $\mathbf{1}$ is microsclerodermin D, which carries also a 6'-chloro-tryptophan, but lacks the 5- 


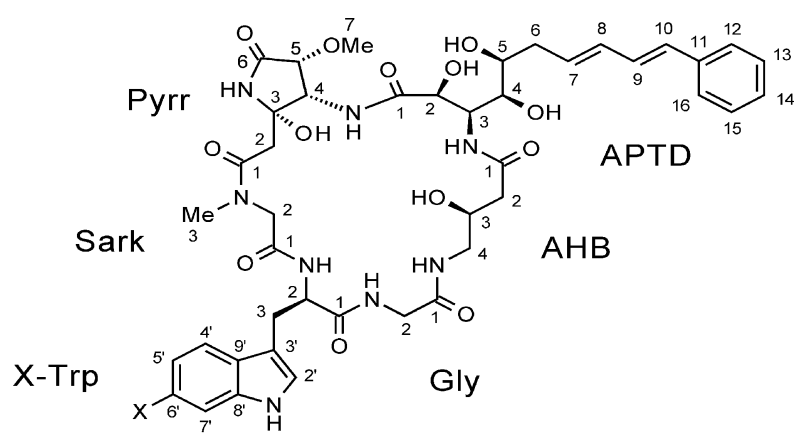

Pedein $\mathrm{A} \quad \mathrm{X}=\mathrm{Cl}$ (1)

$\mathrm{B} X=\mathrm{H} \quad(2)$

Fig. 2 Structures of pedein A (1) and B (2).

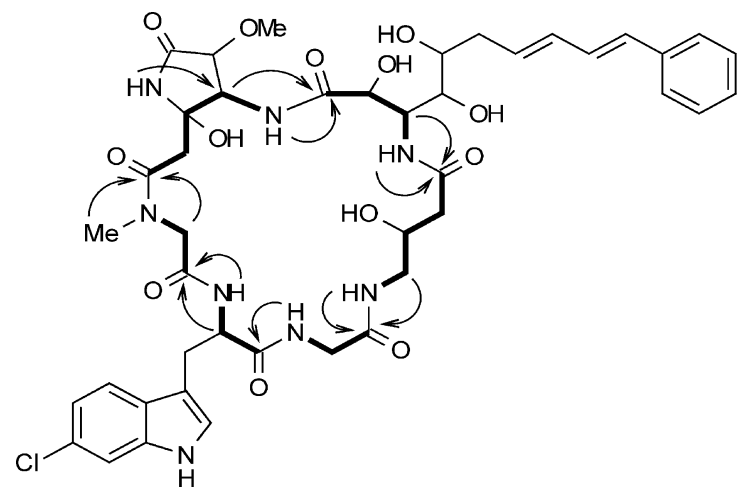

Fig. 3 Amino acid sequence specific correlations from the HMBC NMR spectrum of pedein A (1).

methoxy group of Pyrr, and one of the two C,C-doublebonds of APTD. The optical rotation of $1\left(\alpha_{\mathrm{D}}-46.5\right)$ and microsclerodermin $\mathrm{D}\left(\alpha_{\mathrm{D}}-56\right)$ are similar, proton and carbon chemical shifts and coupling constant of comparable partial structures nearly identical. Thus, it may be safely assumed that the absolute configuration as well as the conformation of $\mathbf{1}$ core-structure is identical to microsclerodermin D.

2 according to ESI-MS lacks the chlorine substituent and shows NMR spectral data identical to $\mathbf{1}$ with the exception of an unsubstituted indole ring.

\section{Biological Properties}

1 inhibited the growth of a broad spectrum of yeasts and fungi, while bacteria were not sensitive to the antibiotic (Table 4). MIC for Rhodotorula glutinis was $0.6 \mu \mathrm{g} / \mathrm{ml}$, for both Saccharomyces cerevisiae and Candida albicans $1.6 \mu \mathrm{g} / \mathrm{ml}$, and for Ustilago maydis $3.1 \mu \mathrm{g} / \mathrm{ml}$. For cultivated L929 mouse fibroblasts 1 showed only weak cytotoxicity with an $\mathrm{IC}_{50}$ of $1.1 \mu \mathrm{g} / \mathrm{ml}$. 1 proved to be highly hemolytic. In a two step dilution assay with $10 \%$
Table 4 1: Biological Activity

\begin{tabular}{|c|c|}
\hline $\begin{array}{l}\text { Test organismª } \\
(\mathrm{mm})\end{array}$ & $\begin{array}{l}\text { iameter of inhibition } \\
\text { zone }^{\mathrm{b}}(\mathrm{mm})\end{array}$ \\
\hline \multicolumn{2}{|l|}{ Gram-negative bacteria } \\
\hline Escherichia coli DSM 423 & 0 \\
\hline Enterobacter aerogenes & 0 \\
\hline Pseudomonas aeruginosa DSM 1117 & 0 \\
\hline Salmonella typhimurium DSM 5091 & 0 \\
\hline \multicolumn{2}{|l|}{ Gram-positive bacteria } \\
\hline Bacillus subtilis DSM 10 & 0 \\
\hline Brevibacterium ammoniagenes DSM 20306 & 0 \\
\hline Corynebacterium fascians DSM 20131 & 0 \\
\hline Micrococcus luteus $\mathrm{GBF}^{\mathrm{d}} 26$ & 0 \\
\hline Staphylococcus aureus GBF 16 & 0 \\
\hline \multicolumn{2}{|l|}{ Yeasts } \\
\hline Candida albicans GBF 129 & 32 \\
\hline Candida utilis & 27 \\
\hline Rhodotorula glutinis & 28 \\
\hline Saccharomyces cerevisiae GBF 36 & 20 \\
\hline Schizosaccharomyces pombe Tüe 501 & 24 \\
\hline Torulopsis glabrata DSM 70398 & 23 \\
\hline \multicolumn{2}{|l|}{ Filamentous fungi } \\
\hline Botrytis cinerea DSM 877 & 22 \\
\hline Gibberella fujikuroi DSM 893 & 26 \\
\hline Pythium debaryanum DSM 62948 & 27 \\
\hline Rhizopus arrhizus DSM 905 & 35 \\
\hline Trichoderma koningii DSM 63060 & 23 \\
\hline Ustilago maydis & 27 \\
\hline
\end{tabular}

a Bacteria were tested on nutrient agar, fungi on malt extract peptone agar.

${ }^{\mathrm{b}}$ Determined by the agar diffusion test with $20 \mu \mathrm{g}$ pedein per 6-mm paper disc.

${ }^{c}$ Deutsche Sammlung von Mikroorganismen.

${ }^{d}$ Strain of the GBF, Dept. of Natural Biology.

${ }^{e}$ Collection University Tübingen.

sheep blood in $0.9 \% \mathrm{NaCl}$ solution, the addition of $100 \mu \mathrm{g} / \mathrm{ml}$ down to $1.8 \mu \mathrm{g} / \mathrm{ml}$ led to the immediately lysis of the erythrocytes. The $\mathrm{IC}_{50}$ was $0.8 \mu \mathrm{g} / \mathrm{ml}$. Because of this hemolytic activity, the effect of $\mathbf{1}$ on membrane integrity of the yeast $R$. glutinis was investigated. As Fig. 4 shows, UV absorption of the supernatant at $260 \mathrm{~nm}$ increased under these conditions. The degree and rate of these changes depended on $\mathbf{1}$ concentration applied and showed that 1 indeed causes changes of membrane permeability of sensitive cells.

\section{Discussion}

The pedeins are further new basic structures isolated from 


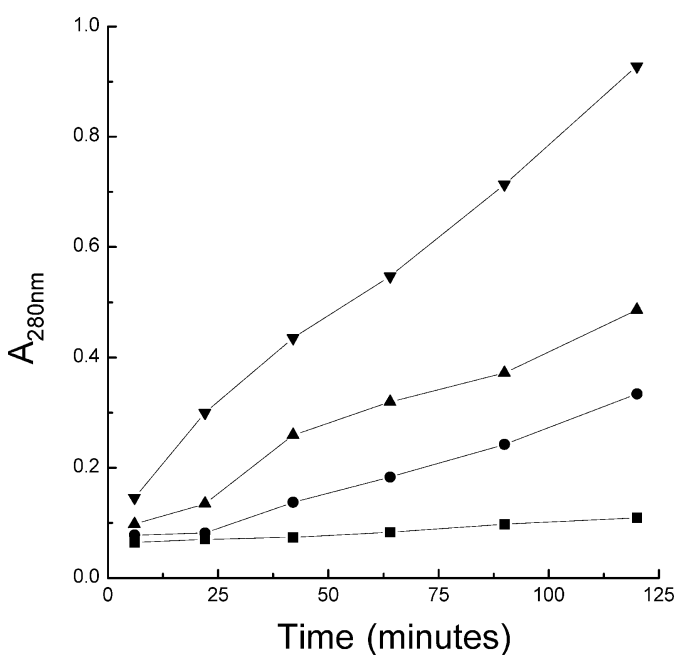

Fig. 4 Effect of pedein A on membrane permeability of Rhodotorula glutinis cells.

Without pedein $\mathrm{A}, \boldsymbol{1} 1.5 \mu \mathrm{g} / \mathrm{ml}$ pedein $\mathrm{A}, \boldsymbol{\Delta} 3.1 \mu \mathrm{g} / \mathrm{ml}$ pedein $A, \nabla 6.2 \mu \mathrm{g} / \mathrm{ml}$ pedein $\mathrm{A}$.

strains of the myxobacterial genus Chondromyces. The structurally unrelated crocacins, chondramides, chondrochlorens, and ajudazols are simultaneously produced by all strains of the species $C$. crocatus screened and show different mechanisms of action [1 10]. While the cytotoxic V-ATPase inhibitors apicularen [8 10] were widely distributed in most of the other Chondromyces species, the new pedeins were hitherto only found in C. pediculatus, strain Cm p3 and Cm T270. Biological studies showed that especially 1 showed good antifungal activity, which corresponds to the structurally related microsclerodermins. Yet we could find neither potent antitumor activity nor microtubule aberrations as has been described for some of the microsclerodermins $[14,16]$. First investigations into the mechanism of action showed that 1 seem to interfere with membrane integrity. The pedeins are a further example of myxobacterial compounds that are chemically related to metabolites isolated from marine sponges. After myxobacterial saframycin MX1 [17], which is chemically related to renieramycin from the sponge Reniera sp. [18], the chondramides [1 3], which resemble jasplakinolide from the sponge Jaspis johnstoni [19], the apicularens $[8,9]$, which are structurally related to the salicylihalamides from Haliclona sp. [20], and rhizopodin [21] which resembles sphinxolid B from the deep sea sponge Nosiphonia superstes [22], the pedeins resemble the microsclerodermins, which have been isolated by Faulkner and co-workers from several species of the lithistid sponges Microscleroderma sp. and Theonella sp. [12 14]. It is remarkable that chemically closely related but otherwise unique compounds occur in phylogenetically so distant organisms as myxobacteria and marine sponges. However, recently it was shown, that one of such peptides, namely theopalauamide from Theonella swinhoei is located in and presumably produced by a symbiotic proteobacterium, Candidatus Entoheonella palauensis that is by $16 \mathrm{~S}$ rRNA analysis closely related to terrestrial myxobacteria [23]. Most remarkably, microsclerodermins $\mathrm{C} \sim \mathrm{E}$ have also been isolated from Theonella species in addition to theopalauamide [13]. Thus theopalauamide related compounds may likewise be discovered in myxobacteria in the future. On the other hand, one could hypothesize that more relatives of myxobacterial metabolites will be discovered in the future in sponges having been produced by their bacterial feed or bacterial symbionts genetically related with myxobacteria.

\section{Experimental}

\section{General}

Spectral and physico-chemical data were obtained with the following instruments: Optical rotation, Perkin Elmer 241 MC polarimeter; UV, Shimadzu UV/Vis-2102 PC spectrometer. IR, Nicolet 20 DXB FT-IR spectrometer; NMR, Bruker DMX-600 spectrometer $\left({ }^{1} \mathrm{H}: 600 \mathrm{MHz},{ }^{13} \mathrm{C}\right.$ : $150 \mathrm{MHz}$ ). HPLC/DAD/ESI-MS: PE Sciex Api-2000 LC/MS; Nucleodur C18 column, $5.0 \mu \mathrm{m}, 2 \times 125 \mathrm{~mm}$ (Machery-Nagel) $\left(0.3 \mathrm{ml} /\right.$ minute $\mathrm{CH}_{3} \mathrm{CN} / 5 \mathrm{mM}$ ammonium acetate buffer $\mathrm{pH} 5.5$ gradient 5:95 to $95: 5$ in 30 minutes). ESI-MS: TSQ 700 (Finnigan MAT) (solvent $\left.\mathrm{CH}_{3} \mathrm{OH} / \mathrm{CH}_{3} \mathrm{CN} / \mathrm{H}_{2} \mathrm{O} / \mathrm{HCOOH} 4: 2: 1: 0.1\right)$. GC/MS: Carlo Erba Mega series gas chromatograph interfaced with a Kratos MS50 fast-scan mass spectrometer (+EI); column: $30 \mathrm{~m} \mathrm{DB} 1$; gradient: 5 minutes isotherm at $60^{\circ} \mathrm{C}$, then $10^{\circ} \mathrm{C} /$ minute to $300^{\circ} \mathrm{C}$; carrier gas He. FAB-MS: Kratos MS50 RF TC instrument equipped with a high field magnet and using a $8 \mathrm{kV}$ Xenon beam. Approximately $10 \mu \mathrm{g}$ of sample was dissolved in 3-nitrobenzylalcohol. Spectra were recorded with an acceleration potential of $8 \mathrm{kV}$ and a magnet scan rate of 10 seconds/decade. High-resolution data were acquired by peak matching at a resolution of approximately 8000 using PEG.

\section{Producing Microorganism and Culture Conditions}

Chondromyces pediculatus strain $\mathrm{Cm} \mathrm{p} 3$ was isolated at the Helmholtz Centre for Infection Research (formerly GBF) in 1982 from a soil sample collected in Key Largo, Florida, USA. Later on pedein A was also detected in strain $\mathrm{Cm}$ T292, which was isolated from a soil sample from Costa Rica. Initially Strain Cm p3 was grown on VY/2 [24] agar plates and in MD1 [24] liquid medium supplemented with 
$1 \mathrm{ml} /$ liter of each of a standard vitamin and a trace element solution. Batch cultures of 20,100 or $400 \mathrm{ml}$ in $100-\mathrm{ml}$, 250-ml or 1,000-ml Erlenmeyer flasks, respectively, were incubated at $30^{\circ} \mathrm{C}$ on a rotary shaker at $160 \mathrm{rpm}$ for $4 \sim 7$ days. $\mathrm{Cm}$ p3 grew in small clumps. After the strain had been adapted to growth in liquid media by $4 \sim 8$ transfers in shaken cultures, it also could be cultivated in media containing various technical substrates e.g. Probion (single cell protein prepared from Methylomonas clarae; Hoechst AG, Frankfurt), soy flour (Tipo S, gift from Novartis) or oatmeal.

\section{Fermentation and Isolation}

Batch fermentations of $C$. pediculatus strain $\mathrm{Cm}$ p3 were performed in media on the basis of technical substrates. To give an example, eleven $400-\mathrm{ml}$ cultures in 1-liter Erlenmeyer flasks grown for 3 days in soy flour liquid medium (soy flour $0.4 \%$, soluble starch $0.3 \%, \mathrm{MgSO}_{4}$. $7 \mathrm{H}_{2} \mathrm{O} 0.15 \%, \mathrm{CaCl}_{2} \cdot 2 \mathrm{H}_{2} \mathrm{O} 0.05 \%$, vitamin $\mathrm{B}_{12} 0.25 \mathrm{mg} /$ liter, and $1.0 \mathrm{ml} /$ liter of a standard trace element solution, HEPES $50 \mathrm{mM}, \mathrm{pH} 7.2$ ) on a gyratory shaker at $160 \mathrm{rpm}$ were inoculated into 65 liters of the same medium without the addition of HEPES in a type b 50 bioreactor (Giovanola Frères, Monthey, Switzerland). In order to reduce foam formation, $0.05 \%$ silicone antifoam agent (Tegosipon, Goldschmidt AG, Essen) was added. The bioreactor was kept at $30^{\circ} \mathrm{C}$ and agitated at $100 \mathrm{rpm}$ with a turbine plate stirrer. The aeration rate was 0.05 volume air per culture volume and minute and the $\mathrm{pH}$ value was regulated during fermentation at $\mathrm{pH}$ 7.0. The $\mathrm{pO}_{2}$ in the culture was recorded continuously with a polarographic oxygen electrode and remained during the whole fermentation between 90 and $83 \%$, respectively. On day 7 the fermentation was terminated by centrifugation of the culture broth at a titer of $1.3 \mathrm{mg} /$ liter $\mathbf{1}$. For isolation of $\mathbf{1}$ and $\mathbf{2}$, wet cell mass from 36 liters of culture from shaking flasks containing $4.0 \mathrm{mg} /$ liter 1 was extracted twice with acetone. After evaporation of the organic solvent and lyophilisation, the crude extract $(6.0 \mathrm{~g})$ was distributed between methanol $(0.5$ liter $)$ and heptane $(5 \times 0.5$ liter $)$. Evaporation of the methanol layer yielded a refined extract $(370 \mathrm{mg}$ ) which was dissolved in a small amount of DMSO and separated in two runs on a HD-Sil-18-20-60 column $(6 \times 54 \mathrm{~cm})$ with the solvent system methanol/water $70: 30$ (detection $206 \mathrm{~nm}$ ). The pedein containing fraction $(113 \mathrm{mg})$ was re-chromatographed on a Nucleosil 100-C18 column $(20 \times 250 \mathrm{~mm})$ with the solvent system methanol/water $60: 40$; yield $67 \mathrm{mg}$ of $\mathbf{1}$ and $8.0 \mathrm{mg}$ of $\mathbf{2}$.

\section{Analysis of Secondary Metabolites}

Secondary metabolite production by $\mathrm{Cm} \mathrm{p} 3$ was monitored by analytical HPLC of acetone cell extracts using a Waters 991 instrument. Chromatographic conditions were as follows: column $250 \times 4 \mathrm{~mm}, 7 \mu \mathrm{m}$, Nucleosil C18, solvent: $\mathrm{MeOH} / \mathrm{H}_{2} \mathrm{O} 60: 40$ or $70: 30$, flow $1.5 \mathrm{ml} /$ minute, detection at $280 \mathrm{~nm}$. Rt for 1 was 10.1 and 5 minutes, respectively. Analytical TLC was performed on silica gel Si 60 F254 aluminium sheets (Merck), solvent: EtOAc/ $/ \mathrm{MeOH} / \mathrm{H}_{2} \mathrm{O}$ $80: 15: 10$, detection UV absorption at $254 \mathrm{~nm}$, and as blue spots after spraying with vanillin/sulfuric acid/heating to $120^{\circ} \mathrm{C}$.

\section{Amino Acid Analysis}

$1(1.0 \mathrm{mg})$ was hydrolyzed [4 N TFA, $100^{\circ} \mathrm{C}, 4$ hours] and the resulting amino acid mixture converted to ethyl esters [ $4 \mathrm{~N} \mathrm{HCl}$ in $\mathrm{EtOH}, 100^{\circ} \mathrm{C}, 1$ hour]. The solvents evaporated in a stream of nitrogen and the residue trifluoroacetylated $\left[100 \mu \mathrm{CH}_{2} \mathrm{Cl}_{2}, 50 \mu \mathrm{l}\right.$ TFAA, $110^{\circ} \mathrm{C}, 15$ minutes]. The solvents were again evaporated in a stream of nitrogen, the residue dissolved in dichloromethane and analyzed by GC/MS: Three major peaks were observed identified by retention time and mass spectrum as glycine and sarcosine and an isomer of threonine which according to NMR data was 4-amino-3-hydroxy-butyric acid (AHB).

\section{Biological Activity}

Standard strains for testing the biological activity were obtained from the DSMZ and the stock collection of our laboratory at the HZI. The antimicrobial spectrum of $\mathbf{1}$ was determined by an agar-plate diffusion assay using paper discs as described previously [25]. The minimal inhibitory concentrations were determined with the conventional serial two-fold dilution method. As inoculum $1 \times 10^{6}$ cells were used, and the antibiotics were dissolved in $\mathrm{MeOH}$, giving $\mathrm{MeOH}$ concentrations in the cultures of not more than 3.0\%. Cytotoxicity against L929 mouse cells (connective tissue, ATCC CCL 1) was determined as reported [26].

\section{Measurement of Membrane Integrity}

To measure the effect of $\mathbf{1}$ on membrane integrity, washed cells of a culture of the yeast $R$. glutinis were suspended in $0.1 \mathrm{M}$ TRIS-HCl buffer to give an optical density of $\mathrm{E}_{546}=1$. After the addition of different concentrations of $\mathbf{1}$ to parallel suspensions, the efflux of UV-absorbing material was measured by determination of the extinction at $260 \mathrm{~nm}$ of the culture supernatant at different times.

Acknowledgements The authors wish to thank Mrs. H. Petrat, N. Malkomes, I. Gronwald and S. Reinecke for skilful technical assistance, and the colleagues of the fermentation service, $\mathrm{H}$. Schüler, R. Krützfeldt, B. Ebert and R. Sterlinski for their help 
with large-scale fermentations. They also wish to thank $\mathrm{H}$. Steinmetz for HPLC/MS analyses, and B. Jaschok-Kentner, Ch. Kakoschke and V. Wray for measuring the NMR spectra and A. Meyer, Ch. Proppe, M. Nimtz and A. Christ for recording the mass spectra. Mammalian cell culture tests by Dr. F. Sasse are gratefully acknowledged.

\section{References}

1. Kunze B, Jansen R, Sasse F, Höfle G, Reichenbach H. Chondramides $\mathrm{A} \sim \mathrm{D}$, new antifungal and cytostatic depsipeptides from Chondromyces crocatus (myxobacteria). Production, physico-chemical and biological properties. J Antibiot 48: 1262-1266 (1995)

2. Jansen R, Kunze B, Reichenbach H, Höfle G. Chondramides $A \sim D$, new cytostatic and antifungal cyclodepsipeptides from Chondromyces crocatus (myxobacteria): Isolation and structure elucidation. Liebigs Ann 1996: 285-290 (1996)

3. Sasse F, Kunze B, Gronewold TMA, Reichenbach H. The Chondramides: Cytostatic agents from myxobacteria acting on the actin cytoskeleton. J Natl Cancer Inst 90: 1559-1563 (1998)

4. Kunze B, Jansen R, Höfle G, Reichenbach H. Crocacin, a new electron transport inhibitor from Chondromyces crocatus (myxobacteria). Production, isolation, physicochemical and biological properties. J Antibiot 47: 881-886 (1994)

5. Jansen R, Washausen P, Kunze B, Reichenbach H, Höfle G. The crocacins, novel antifungal and cytotoxic antibiotics from Chondromyces crocatus and Chondromyces pediculatus (myxobacteria): Isolation and structure elucidation. Eur J Org Chem 1999: 1085-1089 (1999)

6. Jansen R, Kunze B, Reichenbach H, Höfle G. Ajudazols A and $\mathrm{B}$, novel isochromanones from Chondromyces crocatus (myxobacteria): Isolation and structure elucidation. Eur J Org Chem 2002: 917-921 (2002)

7. Kunze B, Jansen R, Höfle G, Reichenbach, H. Ajudazols, new inhibitors of the mitochondrial electron transport from Chondromyces crocatus. Production, antimicrobial activity and mechanism of action. J Antibiot 57: 151-155 (2004)

8. Kunze B, Jansen R, Sasse F, Höfle G, Reichenbach H. Apicularens A and B, new cytostatic macrolides from Chondromyces species (myxobacteria). Production, physicochemical and biological properties. J Antibiot 51: 1075-1080 (1998)

9. Jansen R, Kunze B, Reichenbach H, Höfle G. Apicularen A and B, cytotoxic 10-membered lactones with a novel mechanism of action from Chondromyces species (myxobacteria): Isolation, structure elucidation, and biosynthesis. Eur J Org Chem 2000: 913-919 (2000)

10. Huss M, Sasse F, Kunze B, Jansen R, Steinmetz H, Ingenhorst J, Zeeck A, Wieczorek H. Archazolid and apicularen: Novel specific V-ATPase inhibitors. BMC
Biochemistry 6: 13 (2005)

11. Höfle G. Biologically active secondary metabolites from myxobacteria-isolation and structure elucidation, In Scientific Annual Report of the GBF, Ed. Walsdorff, H.-J., Braunschweig, 1993, pp. 113-117

Höfle G, Reichenbach H. The biosynthetic potential of the myxobacteria. In: Sekundärmetabolismus bei Mikroorganismen. Ed., W. Kuhn, HP Fiedler, pp. 61-78, Attempto Verlag, Tübingen

12. Bewley CA, Debitus C, Faulkner DJ. Microsclerodermins A and B. Antifungal cyclic peptides from lithisted sponge Microscleroderma sp. J Am Chem Soc 16: 7631-7636 (1994)

13. Schmidt EW, Faulkner DJ. Microsclerodermins $\mathrm{C} \sim \mathrm{E}$, antifungal cyclic peptides from the lithistid marine sponges Theonella sp. and Microscleroderma sp. Tetrahedron 54: 3043-3056 (1998)

14. Qureshi A, Colin PL, Faulkner DJ. Microsclerodermins $\mathrm{F} \sim \mathrm{I}$, antitumor and antifungal cyclic peptides from listhid sponge Microscleroderma sp. Tetrahedron 56: 3697-3685 (2000)

15. 1-Phenyl-1,3-pentadiene shows UV bands at $235 \mathrm{~nm}$ ( $\varepsilon=9300), 279$ (27400), 286 (28200), 208 (10400), see e.g.: E. N. Marvell, C. Lin: The aromatic Cope rearrangement. Thermal reactions of cis-1-aryl-2-vinylcyclopropanes. J Amer Chem Soc 100: 877-883 (1978)

16. Wright AE, Pomponi SA, Longley RE, Isbrucker RA. (Harbor Branch Oceanographic Institution, Inc.) US Patent No.: US 6,384,187 B1 (2002)

17. Irschik H, Trowitzsch-Kienast W, Gerth K, Höfle G, Reichenbach H. Saframycin Mx1, a new natural saframycin isolated from a myxobacterium. J Antibiot 41: 993-998 (1988)

18. Frincke JM, Faulkner DJ. Antimicrobial metabolites of the sponge Reniera sp. J Am Chem Soc 104: 265-269 (1982)

19. Scott VR, Boehme R, Matthews TR. New class of antifungal agents: Jasplakinolide, a cyclodepsipeptide from the marine sponge, Jaspis species. Antimicrob Agents Chemother 32: 1154-1157 (1988)

20. Erickson KL, Beutler JA, Cardellina II JH, Boyd MR. Salicylihalamides A and B, novel cytotoxic macrolides from the marine sponge Haliclona sp. J Org Chem 62: 8188-8192 (1997)

21. Sasse F, Steinmetz H, Höfle G, Reichenbach H. Rhizopodin, a new compound from Myxococcus stipitatus (myxobacteria) causes formation of rhizopodia-like structures in animal cell cultures. J Antibiot 46: 741-748 (1993)

22. D'Auria MV, Paloma LG., Minale L., Zampella A., Verbist JF, Roussakis C, Debitus C. Three new potent cytotoxic macrolides closely related to sphinxolides from the New Caledonian sponge Nosiphonia superstes. Tetrahedron 49: 8657-8664 and Corrigendam of structures 10439 (1993)

23. Schmidt EW, Obraztsova AY, Davidson SK, Faulkner DJ, Haygood MG. Identification of the antifungal peptide- 
containing symbiont of the marine sponge Theonella swinhoei as a novel $\delta$-proteobacterium, "Candidatus Entotheonella palauensis”. Mar Biol 136: 969-977 (2000)

24. Reichenbach H, Dworkin M. The myxobacteria. In The Prokaryotes. Vol. 4. Ed., A. Balows, H.G. Trüper, M. Dworkin, W. Harder, K.-H. Schleifer, pp. 3416-3487, Springer-Verlag, New York, 2nd ed. 1992

25. Kunze B, Reichenbach H, Müller R, Höfle G. Aurafuron A and B, new bioactive polyketides from Stigmatella aurantiaca and Archangium gephyra (Myxobacteria). Fermentation, isolation, physico-chemical properties, structure and biological activity. J Antibiot 58: 244-251 (2005)

26. Mosmann T. Rapid colorimetric assay for cellular growth and survival: Application to proliferation and cytotoxic assays. J Immunol Methods 65: 55-63 (1983) 